\title{
The Effect of Sex Education on Knowledge and Attitude in Adolescent with Intellectual Dissability in SLB N 1 Bantul
}

\author{
Rahmah Widyaningrum, Ignasia Nila Siwi ${ }^{1}$ \\ ${ }^{1}$ Sekolah Tinggi Ilmu Kesehatan Madani Yogyakarta, Indonesia \\ Corresponding author : rahmah.widyaningrum@gmail.com
}

\begin{abstract}
Background: There are 3.708 children with intellectual dissability in Yogyakarta. Adolescents with intellectual disability will have limitation on cognitive, adaptive behavior and social-personal function, which lead to some diverted behaviors such as inability to maintain cleanliness, taking care of themselves, and conducting good act of sexual behaviors. These conditions will lead to social perception as childish, inhuman, asexual, or bad sexual behavior due to lack of information and low cognitive function.

Purpose : This study aimed to assess the efect of sex education on knowledge and attitude of adolescent student with intellectual dissability in SLB N 1 Bantul, Yogyakarta.

Methods : This is a pre experimental with one group pre test-post test design. Twenty (20) students with intellectual dissability were recruited using simple random sampling. Knowledge and attitude were measured using questionnaire before and after sex education program for four weeks. The data were analyzed using paired t-test.

Result : There is a significant $(\mathrm{p}=0.000)$ different on the knowledge anda significant $(\mathrm{p}=$ 0.039 ) different on the attitude before and after six-sex education program.

Conclusion : Adolescent with intellectual dissability require specific treatment, communication and skill to improve their knowledge and attitude through sex education program.
\end{abstract}

Keywords : Sex Education, Knowledge, Attitude, Adolescent, Intellectual Dissability 


\section{BACKGROUND}

Children with disabilities in Indonesia reaching around 2.126.998 individuals,290.944 individuals of them are children with intelectual dissabilities(BPS Susenas RI, 2009). There were 3.708 children withdisabilityin Yogyakarta (Dinsos DIY, 2015). Amount of the child with disabilities most likely continue to increase until now.

Recent study reported that $50 \%$ parents of individuals with intellectual disabilities did not give their children with sexual education (Islamiyatur, 2015). They think individuals with intellectual disabilities did not have sexual desire and focused more on preparing their intellectual skills insekolahluarbiasa (SLB) or special school. This condition has led to the increased level of sexual harassment in individuals with intellectual disabilities (Sudiar, 2010).According to The American Academy of Pediatrics, children with intellectual disabilities will experience twice as high as normal children as sexual abusing victims (Yunita, 2011). Interestingly, sexual abuse that occurs in children with intellectual disabilities are carried out by their closest person (Artanto, 2014).This condition is often worsened by bad influence of sexual lifestyles, attitudes and behavior received from internet, social media, television, etc (Novita, 2006).Therefore, parents should understand the importance of sexual education to fulfil their sexual or reproductive rights as human being as well to prevent sexual abusing activities (Astuti, 2013; Puspita, 2008 in Sudiar, 2010).

Although schools are ideal places to provide information on adolescent reproductive health, for example information about sexual behavior, pregnancy and eastern culture about sexuality concerning norms and religion, however, parents and families are the first party responsible for providing information on adolescent sexual education (Haslegrave\&Olatunbsun, 2003; Soetjiningsih, 2004). Information regarding sexual behavior is important to prevent individuals with intellectual disabilities performing bad sexual behavior such as playing with their genitals, holding or rubbing directly of their genitals over the wall and doing masturbation in the public (Sudiar, 2010).

Haryono, TJS (2013) found that there were still many women with disabilities who did not understand the care of reproductive organs. People with disabilities are very lacking in access to sexual information. Persons with disabilities need information about menstruation and how to put on pads, wash pads, remove pads and others. Sexual and reproductive health education cannot be given directly to women with disabilities but can be provided through their parents (Piotrowski and Snell,2007).

\section{OBJECTIVE}

This study aimed to assess the efect of sex education on knowledge and attitude of adolescent student with intellectual dissability in SLB N 1 Bantul, Yogyakarta.

\section{METHODS}

This study is a pre experimental design with one group pretest-posttest approach. The study was conducted at SLB N 1 Bantul. The study sample was all children with intellectual disabilities as many as 20 people, using simple random sampling method. The inclusion criteria set by the researcher are as follows: 1) Adolescent with intellectual disabilities with ages 11 to 17 years; 2) Adolescent with intellectual disabilities with mild and moderate categories; 3) Adolescent with intellectual disabilities who are willing to become respondents and follow the research until the end. While the exclusion criteria are adolescents with intellectual disabilities in the heavy category.In this study, we performed 
sex education program that involved 6 sex education sessions. The topics included: 1) body care and hygiene, 2) self-assertiveness training, 3) manners in public spaces, 4) sexual abuse, and 5) male and female relationships; 6) differences between male and female bodies. Research data were analyzed using Paired t-test.

\section{RESULTS}

1. Characteristics of Adolescentswith Intellectual Disability

Majority of the subjects are male (75\%), aged 14-17 years old (55\%), and higher senior education level (65\%).

Table 1. Characteristics of Youth Respondents with Intellectual Disability in SLB N Negeri 1 Bantul $(n=20)$

\begin{tabular}{lcc}
\hline Characteristics of Youth Respondents & $\begin{array}{c}\text { Frequency } \\
\text { (people) }\end{array}$ & $\begin{array}{c}\text { Persentage } \\
\text { (\%) }\end{array}$ \\
\hline Age & 1 & 5 \\
$\quad$ Early Adolescent (<14 y.o) & 11 & 55 \\
Intermediate Adolescent (14-17y.o) & 8 & 40 \\
$\quad$ Late Adolescent ( $>17$ y.o) & & \\
\hline Education level & 13 & 65 \\
$\quad$ Junior High School & 7 & 35 \\
Senior High School & & \\
Sex & 15 & 75 \\
$\quad$ Male & 5 & 25 \\
Female & & \\
\hline
\end{tabular}

Based on the table, it is reported that most subjects are at intermediate adolescent. At this level, adolescentswill have unstable emotions due to their unclear status, leading to pursuit of identity. However, parents usuallyhave little time to accompany their children and tend to busy with their careers or jobs, so there is a lack of special attention. Even though at this age the sex drive is very passionate and courageous attitude to experiment is still firmly planted in the souls of middle adolescents without knowing the adverse effects of it. Therefore, parents must be careful to sublimate the above through spiritual education, recreation, sports or art (Fathunaja, 2015).

2. Sexual Knowledge of Adolescents with Intellectual Disability

Table 2. Sexual Knowledge of Youth with Intellectual Disabilityin SLB N Negeri 1 Bantul $(n=20)$

\begin{tabular}{lcc}
\hline Characteristic & Frequency & Presentage (\%) \\
Information about sex & 12 & 60 \\
$\quad$ Ever & 8 & 40 \\
Not yet & & \\
First Got Sex Education & 6 & 30 \\
$\quad$ Elementary School & 8 & 40 \\
$\quad$ Junior High School & 6 & 30 \\
$\quad$ Senior High School & & \\
Source of Information & &
\end{tabular}




$\begin{array}{lcc}\text { TV/ radio/ magazine } & 4 & 20 \\ \text { Leraning in School } & 4 & 20 \\ \text { Friends } & 8 & 40 \\ \text { Parents } & 4 & 20 \\ \text { Type of Information } & & \\ \quad \text { Pictures } & 8 & 40 \\ \text { Article } & 8 & 40 \\ \text { Video } & 4 & 20 \\ \text { First Age of Wet Dream } & & \\ <14 \text { years old } & 5 & 33,3 \\ 14-17 \text { yeras old } & 10 & 66,7 \\ >17 \text { yeras old } & 0 & 0 \\ \text { Age of menarche } & & \\ <13 \text { years old } & 1 & 20 \\ 13-16 \text { years old } & 2 & 40 \\ >16 \text { years old } & 2 & 40\end{array}$

Based on Table 2, it can be seen that more than half $(60 \%)$ of the total of the respondents had been given sex education. Eight (8) students $(40 \%)$ received their first sex education at junior high school level, 6 students $(30 \%)$ got their sex education during elementary school, and other 6 students (30\%) got new sex education during high school level. Early sex education is important to reduce the risky sexual behavior. Study conducted by Grossman et al (2014) reported that implementation of sex education reduced around $15-16 \%$ of male and female students committed sexual deviations compared to male and female in comparative schools.

\section{Effect of Sex Education Program onKnowledge and Attitude}

The average total social score before the six sex education was increased after 4 weeks intervention of six-sex education program. Paired t-test analysis showed a statistical difference $(\mathrm{p}=0.034)$, which indicated that six-sex education program significantly increased the level of social skills in adolescent with intellectual disabilities.

Table 3.Paired t-test analysis $(n=20)$

\begin{tabular}{lccc}
\hline \multicolumn{1}{c}{ Variable } & Pre-test & Pos-test & Sign $(\mathrm{p})$ \\
\hline Knowledge & $18,85 \pm 4,38$ & $33 \pm 3,65$ & 0,000 \\
\hline Attitude & $25,55 \pm 2,94$ & $36,5 \pm 5,74$ & 0,039 \\
\hline
\end{tabular}

\section{DISCUSSION}

\section{Characteristics of Adolescentswith Intellectual Disability}

Sex education takes an important role in the daily survival of middle-aged adolescents. This is in line with the international agreement in Cairo 1994 (The Cairo Consensus) concerning reproductive health, which was successfully signed by 184 countries including Indonesia. It was decided that sex education is needed for teenagers. The consensus emphasized the efforts to seek and formulate sexual and reproductive health care and provide comprehensive information for teenagers (Purnama, 2013). 
According to Tridayani (2018), there is a positive influence of sexual education carried out in schools on student's sexual behavior. According to Purnama (2013), sex education is important to be included in the curriculum of secondary schools because most of the students are experiencing puberty. Sex education is considered important for anticipating or preventing free sex behavior and being able to avoid other negative effects. The majority (65\%) level of education in this study is junior high school level.The majority $(75 \%)$ of respondents who met the inclusion criteria were male while the remaining $(25 \%)$ respondents are female. Men are prioritized in getting sex education because men are more likely to prioritize sexual aspects than women (Mullinax et al., 2015).

\section{Sexual Knowledge of Adolescents with Intellectual Disability}

When subjects are asked about how they get information regarding sex information, majority $(40 \%)$ of subjects answered friends.Moreover, most of the sex information are acquired through images and articles (each $40 \%$ respectively). This result indicate that subjects may receive deviant information regarding sex from their pairs as well the media. This result in similar with Miligan (2018) who reported that children received information about sexuality from their pairs. This information is not be accurate as youth or their pairs is not capable of having sexual knowledge (Haryono et al., 2013).

In this study, majority of the age of the first wet dream or nocturnal emission for male respondents ranged between the ages of 14-17 years. For female respondents, the age of subjects having their first menstrual cycle is between 13-16 years old and above 16 years old.Our result is supported by research conducted by Triyanto (2010) which states that teenage boys experience nocturnal emission at the age of 14 years. This condition is a normal physiological processes in male adolescentsthatmaturity of testes located at the scrotum begins at the age of 14 years.Moreover, women also experienced their first menstrual cycle at the age of 1314 years, which is similar in accordance to the Results of Basic Health Research in 2010 (Mutasya, et al 2016).

\section{Effect of Sex Education Program onKnowledge and Attitude}

The average total social score before the six sex education was increased after 4 weeks intervention of six-sex education program. Paired t-test analysis showed a statistical difference $(\mathrm{p}=0.034)$, which indicated that six-sex education program significantly increased the level of social skills in adolescent with intellectual disabilities.

The purpose of sex education programs is to improve sexual health, which is defined not only as a lack of illness or negative experience regarding sexuality, but includes positive aspects, such as: the possibility of having a pleasant and safe sexual experience (WHO, 2006). In practice, sexual health is not only about preventing sexually transmitted infections (STIs), unplanned pregnancies and negative sexual experiences, but also about providing a means for people to experience sexuality in a positive way, namely through sex education programs (Schaalma, H, 2009 ).

Although our study reported the beneficial effect of sex education on improving social skills of children with intellectual disabilities, however, there are still discrepancies on literature regarding the best and effective method for teaching sex 
education. Most studies in the review do not provide details about what is taught, why it is taught and how it is taught, but mainly focuses on whether sex education has an effect on knowledge, attitudes or skills (Schaafsma et al., 2015). More information is needed about what needs to be taught to people with intellectual disabilities related to sexuality and how this is taught. Women with intellectual disabilities is one group that require more attention on sexual education. According to Haryono (2013), women with intellectual disabilities have less concern about their reproductive organs such as changing pads when they have menstruation. As a result, women with intellectual disabilities will experience more sexual violence and unwanted pregnancy. Moreover, parents who had children with intellectual disabilities tend to believe that their reproductive is disturbed, thusresulted in limited information regarding to sexuality in women with disabilities (Haryono, 2013).

The importance role of sex education is Haryono (2013) states that ordinary people think that children with disabilities must experience disability in sexual function. This view has resulted in families often limiting women with disabilities from all things related to sexuality. One of them closes them from sexual education. Changes that occur in their bodies such as breast enlargement, hair growth around the genitals, the menstrual process, and things related to other sexuality often do not explain the causes and consequences. The effects of such changes such as the use of underwear and pads are carried out with the command, instructions and supervision of those around them. Even sometimes all of that is done also for the full help of others. The provision of information related to organ development and sexual function experienced by women with disabilities in adolescence is considered not something important. As a result, they did not know the causes and consequences of changes in their bodies.

According to Anderson and Kitchin (2000), women with intellectual disabilities still have passion and love. They tend to seek sexual satisfaction in which information regarding sexuality is important. Limited information in women with intellectual disabilities will result in unsafe sex that cause detrimental effect on their health (Kaplan, 2006). Moreover, this information is important to protect their reproductive organs from infection. Acording to Pratama, R (2013), changes in attitude in these respondents are inseparable from the knowledge processincrease. Previous respondents do not know to know, then understandwill make to changes the attitude pattern.

In this study, we performed sex education program that involved 6 interactive sex education sessions. There are 6 topics with aims to improve social skills in student with intellectual disabilities. The topics included: 1) body care and hygiene, 2) self-assertiveness training, 3) manners in public spaces, 4) sexual abuse, and 5) male and female relationships; 6) differences between male and female bodies. This program is a modified version of the research conducted by Hayashi (2011), where researchers reduce the number of topics and adjust to the beliefs and rules in Islamic religion.Most of the respondents show great interest because information was delivered through mannequin of human body specimen.

In the 6interactive sex education sessions, the researcher then detailed the subtopic of the material presented. In the first session on the differences between male and female bodies, the researcher explained about: the structure of male and female reproductive organs, physical characteristics of men and women, menstrual cycles, 
wet dreams, and circumcision. In the second session on body care and hygiene, researchers explained about: ways to maintain the cleanliness of the genitals, procedures for bathing in junub, aurat of male and female genitals, adornment and dressing, tomboy prohibition. In the third session concerning self-presenting in public, explained about: the rights and obligations of men and women, prohibitions on promiscuity. In the fourth session concerning the relationship of men and women, the researcher explained about: the ethics of chatting and sleeping in the house, the knowledge of promiscuity, diseases due to free sex in both men and women, the prohibition of dating and adultery, prohibition on deviant sexual behavior (masturbation). In the 5th session on sexual harassment, it was explained about: forms of sexual harassment, how to deal with acts of sexual harassment, the influence of online media on sexual violence. At the 6th session on the ethics of asking for permission to enter a parent's room, it was explained about the prohibition of peeping and the ethics of entering the parent's room.

Knowledge is the result of knowing by someone and occurs after sensing a particular object. In the process of health education there is a reciprocal influence between various factors, including: the subject of learning, teaching, learning methods and techniques, learning aids and material or material learned. While output is the result of the learning process, which is in the form of ability and behavior changes from the subject of learning. The method used when conducting health education also affects the increase in knowledge (Notoatmodjo, 2007). According to Mubarak \&Chayatin (2009) attitudes are the tendency to accept or reject actions and not an activity. Lubis (2013) explains that there is an effect of health education on lecture methods on changes in students' knowledge and attitudes.

This study serves to increase knowledge, skills and attitudes towards topics related to sexuality. The topic and the method performed in this study are generally very broad and generic becauseno articles that provide a justification for the choice of topics or methods used in the program. In addition, the purpose of the program or material in most cases is not reported in the article. In addition, no support can be found which shows that sex education programs have been developed systematically or based on theory and evidence. The methods used to target skills and or enhance their knowledge are: feedback (corrective), role play, practice skills (guided training, modeling, training, reinforcement, image or drawing, and discussion (Schaafsma, D, 2015).

\section{CONCLUSION}

The provision of a six-sex education program with effective lecture, demonstration and evaluation techniques improves the social skills of adolescents with intellectual disabilities regarding sexuality in SLB Negeri 1 Bantul.

\section{ACKNOWLEDGEMENT}

We thank Principal, Teacher Staff, and SLB N 1 Bantul students for participating in this study.This study was funded by Beginner Lecturer Research Grant (PDP) program from Ministry of Research, Technology and Higher Education of the Republic of Indonesia. 


\section{REFERENCES}

Artanto. 2014. Pengaruh Penyuluhan Kesehatan terhadap Sikap Dalam Memberikan Pendidikan Seksual Dini Pada Anak Usia 9-12 Tahun di Pedukuhan Pundung dan Karangtengah Nogotirto Gamping Sleman. Skripsi. Stikes Aisyiyah Yogyakarta

Dinsos DIY. (2015).Jumlah penyandang disabilitas di DIYdalam http://www.dinsos.jogjaprov.go.id, diakses tanggal 20 November 2017

Grossman, Jennifer M et al. 2014. Protective Effects of Middle School Comprehensive Sex Education with Family Involvement. eric.ed.gov. diakses pada 20 Mei 2018.

Haryono,T., Kinasih, SE., Mas'udah, S. 2013. Akses dan informasi bagi perempuan penyandang disabilitas dalam pelayanan kesehatan reproduksi dan seksualitas. Masyarakat, Kebudayaan dan Politik Vol. 26, No. 2, tahun 2013, hal. 65-79.

Haslegrave M, Olatunbosun O. 2003. Incorporating sexual and reproductive health care in the medical curriculum in developing countries. Reprod Health Matters. 2003 May;11(21):49-58.

Hayashi, M., Arakida, M., \& Ohashi, K. (2011). The effectiveness of a sex education program facilitating social skills for people with intellectual disability in Japan. Journal of Intellectual and Developmental Disability, 36, 11-19. http://dx.doi.org/10.3109/13668250.2010.549463

Islamiyatur, (2015). Identifikasi Kebutuhan Kesehatan Reproduksi Bagi Remaja Perempuan Difabel (Tuna Grahita) Di SLB Negeri 2 Yogyakarta. Jurnal Kebidanan

Kementrian Pemberdayaan Perempuan dan Perlindungan Anak. 2011. Undang-Undang Nomor 19 Tahun 2011 tentang Pengesahan Convention on the Rights of Persons with Disabilities (Konvensi Mengenai Hak-Hak Penyandang Disabilitas) (Lembaran Negara Republik Indonesia Tahun 2011 Nomor 107, Tambahan Lembaran Negara Republik Indonesia Nomor 5251).

Milligan, A. 2018. Practical resources available to make sex education easier. Altogetherautism.org.nz. diakses pada 20 Mei 2018.

Mubarak \& Chayatin (2009),Sikap Manusia Teori dan Pengukur. Edisi kedua. Yokyakarta : Pustaka Pelajar.

Mullinax et al. 2015. In Their Own Word: A Qualitative Content Analysis of Women's and Men's Preferences for Women's Genitals. www.ncbi.nlm.nih.gov. diakses pada 20 Mei 2018.

Mutasya, dkk. 2016. Faktor-Faktor yang Berhubungan dengan Usia Menarche Siswi SMP Adabiah.http://jurnal.fk.unand.ac.id. diakses pada 20 Mei 2018.

Notoatmodjo, S. 2012. Promosi Kesehatan Dan Perilaku Kesehatan Edisi 1. Jakarta : Rineka Cipta.

P. Anderson, R. Kitchin. 2000. Disability, space and sexuality: access to family planning Services. Social Science \& Medicine 51 (2000) 1163-1173

Purnama, D S. 2013. Pentingnya "Sex Education" bagi Remaja. www.uny.ac.id. Diakses pada 17 Mei 2018.

Schaafsma, D., Kok, G., Stoffelen, J.M.T., Curfs, L.M.G.: Identifying effective methods for teaching sex education to people with intellectual disabilities: a systematic review. J. Sex Res. 52, 412-432 (2015)

Soetjiningsih. 2004. Tumbuh Kembang Remaja dan Permasalahannya. Jakarta : Sagung Seto 
Sudiar, Resna Riksagiati. 2010. Penanganan Perilaku Seksual Remaja Autis Di Sekolah Luar Biasa Negeri Pembina Yogyakarta (Studi Kasus-Pendekatan Model Kualitatif). Yogyakarta: Universitas Islam Sunan Kalijaga.

Szymanski LS, Kaplan LC. Essentials of child and adolescent psychiatry. Dulcan M, Wiener JM, editors. Arlington, VA: American Psychiatric Publishing; 2006. pp. 121154. (Mental retardation).

Tridayani, N. 2018. Pengaruh Pendidikan Seks terhadap Perilaku Seksual Peserta Didik SMA Negeri 8 Cirebon. Jurnal Ilmiah Kajian Islam Vol 2. No 2.

Triyanto, E. 2010. Pengalaman Masa Pubertas Remaja Studi Fenomenologi di Purwokerto. Jurnal Ners Vol 5 No 2.

World Health Organization: Sexual health document series. Defining sexual health. Report of a technical consultation on sexual health, 28-31 January 2002, WHO Press, Geneva (2006). 